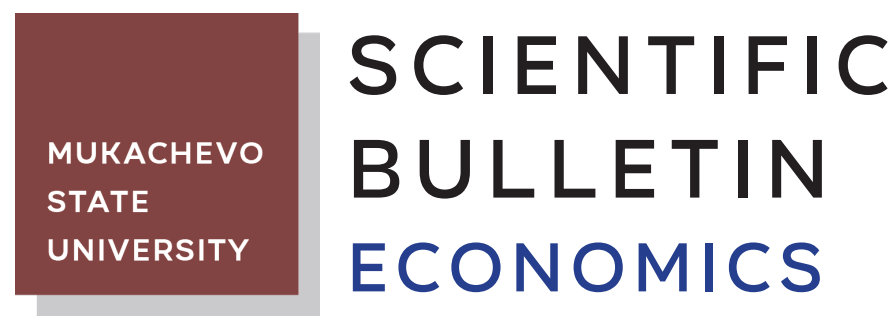

Volume 8, No. 4, 45-52

Journal homepage: https://economics-msu.com.ua/en

\title{
Model of Substantiation of Organizational Structure of the Management System of Higher Education
}

\author{
Serhiy O. Kramskyi', Anna Yu. Strenkovska², Oleg V. Zakharchenko ${ }^{2 *}$ \\ ${ }^{1}$ Odessa Institute of Interregional Academy of Personnel Management \\ 65003, 19 Chornomorske Kozatstvo Str., Odesa, Ukraine \\ ${ }^{2}$ Odessa State Academy of Civil Engineering and Architecture \\ 65029, 4 Didrikhson Str., Odesa, Ukraine
}

\begin{abstract}
The relevance of the research is determined by the need to update the management structure of scientific projects within higher educational institutions in accordance with modern economic realities and internationally recognized standards, the essence of which is the transition from a rigid hierarchical management system and orientation towards the commercialization of the results of scientific and technological activities. Therefore, the purpose of this scientific article is to develop a functional model for scientific project management within higher education, the components of which, unlike existing models, will be characterized by a project-oriented direction. To achieve a certain research goal, general scientific research methods were used, including analysis, synthesis, generalization, comparison, systematization, modeling, as well as structural and mathematical methods, taking into account the key principles of structural-functional and system approaches. The article analyzes a number of scientific works of Ukrainian and foreign scientists on the topic of methodological substantiation of the specifics of management of research projects in higher educational institutions. The key concerns of the current state of scientific project management within the Ukrainian scientific space have been identified, in particular, the rigid organizational and staff management structure with the predominant role of the top management, insufficient financial support of scientific and technical activities, as well as limited access to the results of scientific and technical activities. The author's economic and mathematical model of scientific project management in higher education institutions has been developed considering functional indicators. It is proposed to introduce a body for commercialization of the results of scientific and technical activities, which will help optimize the financial support of scientific and technical activities. The necessity of developing international cooperation within the framework of scientific and technical activities and the organization of scientific projects in particular is substantiated. The practical value of scientific work lies in the development of the author's own methodological support for the proper functioning of scientific project management with the prospect of its further application in practice
\end{abstract}

Keywords: economic model, scientific project, higher educational institutions, scientific and technical activities

Received: 15.09.2021, Revised: 16.10.2021, Accepted: 18.11.2021

Suggested Citation: Kramskyi, S.O., Strenkovska, A.Yu., \& Zakharchenko, O.V. (2021). Model of substantiation of organizational structure of the management system of higher education. Scientific Bulletin of Mukachevo State University. Series "Economics", 8(4), 45-52.

${ }^{*}$ Corresponding author 


\section{Introduction}

The modern system of higher education institutions is characterized by a complex and extensive management structure, in particular in the process of conducting scientific research, as a result of which each individual scientific project has a certain number and stamp. Such an organization creates a number of restrictions on access to the results of scientific activities both for the general public of scientists and for representatives of the business environment. This, for its part, leads to a situation in which different scientific institutions, departments and structural units of scientific organizations solve identical problems or symmetrical problems. Thus, the question is about the irrational repeated spending of public financial resources to achieve similar goals, which in the end are not always implemented in time or not implemented at all. Therefore, there is a need to find a proper optimized model of organizational structure in the management system of higher educational institutions, which confirms the relevance of the study.

The issue of scientific project management has repeatedly become the subject of theoretical scientific research by both Ukrainian scientists and representatives of other countries. In particular, the Portuguese authors D. Oliviera, J. Neves, D. Raposo and J. Silva looked for ways to simplify the management of a research project in the context of communication design, focusing on ergonomics and the human factor [1]. Malaysian researchers C.M.M. Chin, A.C. Spowage, E.H. Yap and C.W. Lee studied the planning and management processes of research projects among doctoral students [2]. Scientists have found that doctoral students are not sufficiently aware of the proper use of project management methodologies, as a result of which there is a need to update the organizational framework. Scientists from Australia, Norway and Canada, namely S. Sankaran, R. Muller and N. Drouin, focused on the analysis of collaboration in project management research [3]. In particular, the authors draw attention to international cooperation between developed countries and developing countries, in the context of which the issue of research management is raised. Scientists also conducted an empirical study that provided for determining the prerequisites for international scientific and project cooperation, among which the reputation of leading researchers, the prestige of institutions, etc. were identified [3]. Especially important for scientific intelligence are the achievements of K. Piwowar-Sulej [4]. The scientist conducted an empirical study, during which managers of the financial industry were interviewed, which contributed to further identification of recommendations on management practices in the context of a successful scientific project. Among the Ukrainian researchers of the chosen topic, it is advisable to mention L. Domnin [5], R. Bulhakov, V. Holovan [6], D. Novikov, A. Sukhanov [7], F. Pedan, G. Rudenska, M. Tkachenko, R. Fedorenko [8]. One way or another, these scientists in their works revealed the methodology of modern scientific project management.

It is worth noting that each higher education institution has a certain number of scientific projects, the implementation of which is included in the annual plan. It is obvious that all projects are characterized by an admissible range of time period to start their implementation, the required amount of attracting public financial resources at the stages of implementation, the expected amount of profit from their implementation, and so on. Therefore, there is a need to find ways to implement scientific projects in order to obtain maximum financial benefits in accordance with the dynamics of financial opportunities. This determines the conduct of scientific research, the purpose of which is a development of a model for managing scientific projects in higher education institutions, the structural elements of which, unlike existing models, will be optimized taking into account the experience of project-oriented management.

\section{Materials and Methods}

The study on the chosen topic of substantiation of the organizational structure of the management system in higher educational institutions was conducted in three stages. In particular, during the first stage of scientific exploration, the analysis of the current state of organization of scientific project management in higher education institutions within the Ukrainian scientific space was conducted to identify the problematic aspects of scientific and technical activities that require qualitative and effective solutions. The second stage of scientific research provided for the creation of a model of effective scientific project management in higher educational institutions based on the analyzed problem field, the essence of which was a combination of quantitative, temporary and financial factors of the organization of a scientific-educational project. The third stage of scientific research was aimed at analyzing international practices of managing scientific projects focused on cooperation with individual enterprises of the economic sphere, in order to establish correlative links with Ukrainian practices and search for methods of possible further cooperation within the scientific and practical space.

Achieving this goal of scientific research made it possible to apply general scientific research methods of theoretical and practical directions. In particular, the method of analysis was used during the analysis of scientific and methodological literature of Ukrainian, European and American researchers on the topic of methodology for managing scientific projects, which made it possible to form a characteristic of the current state of research of the problem. The synthesis method helped to combine the results of the process of analyzing the theoretical base of research in the form of literature sources, as a result of which a key problem of scientific and technical activity was identified, the essence of which is the need to commercialize the results of scientific and technical activities. Using the comparison method, common and distinctive features in the management of scientific projects of higher educational institutions within the Ukrainian and global educational space were identified. The generalization method was used to summarize the results of the study in accordance with the conducted theoretical 
and empirical research, highlighting recommendations for improving the process of managing scientific projects through international cooperation, attracting financial resources from external sources, as well as creating a body for commercializing the results of scientific and technical activities. Through to the structural method and the method of systematization, a vertical of management in the system of higher educational institutions was formed, as well as the structural scheme of the subsystem of management of dual-use scientific products was recreated. The mathematical method, as well as the modeling method, contributed to the creation of an approach to solving the problem of optimal planning of a scientific project, which provided for the design of an effective model for managing scientific projects in higher educational institutions in accordance with the criteria of quantity, time and financial resources. The use of the above-mentioned methods of scientific research in accordance with the principles of structural, functional and system approaches ensured the achievement of the goal of scientific research, taking into account a number of economic factors of scientific and technical activities.

At the same time, the research on the selected issues required a detailed analysis of the legislative and regulatory framework of Ukraine to determine the legal aspects of potential scientific and technical activities within the current legislation, so the work used the key positions specified in the Law of Ukraine "On Scientific and Scientific and Technical Activities".

\section{Results and Discussion}

Commercialization of the results of scientific and technical activities as an element of scientific project management

It is worth starting with the fact that the integration of scientific, scientific and technical and innovative activities of higher educational institutions and scientific institutions of the National Academy of Sciences of Ukraine, as well as national branch Academies of Sciences and institutions of higher education of Ukraine is carried out to develop and implement priority scientific programs, research, experimental developments, etc., based on the combination of personnel, financial, technical and organizational resources in accordance with current legislation. For the proper functioning of research processes in scientific organizational structures, including in scientific and pedagogical departments of higher educational institutions, a clear organizational and staff structure and a hierarchical vertical of management are formed [9]. However, some cases (namely the execution of scientific projects) require a certain opportunity to depart from a predetermined hierarchical structure with the decisive role of the top manager in decision-making. This approach focuses on a flexible network system, within which authority is delegated to the project supervisor (Fig. 1). The ability to manage a science unit (a team of scientific project performers) as a dynamically managed organism with free communications has a positive effect on avoiding the spread of false information between project departments, reducing the burden on the top manager and significantly reducing the time limits for reaction and response from the manager.

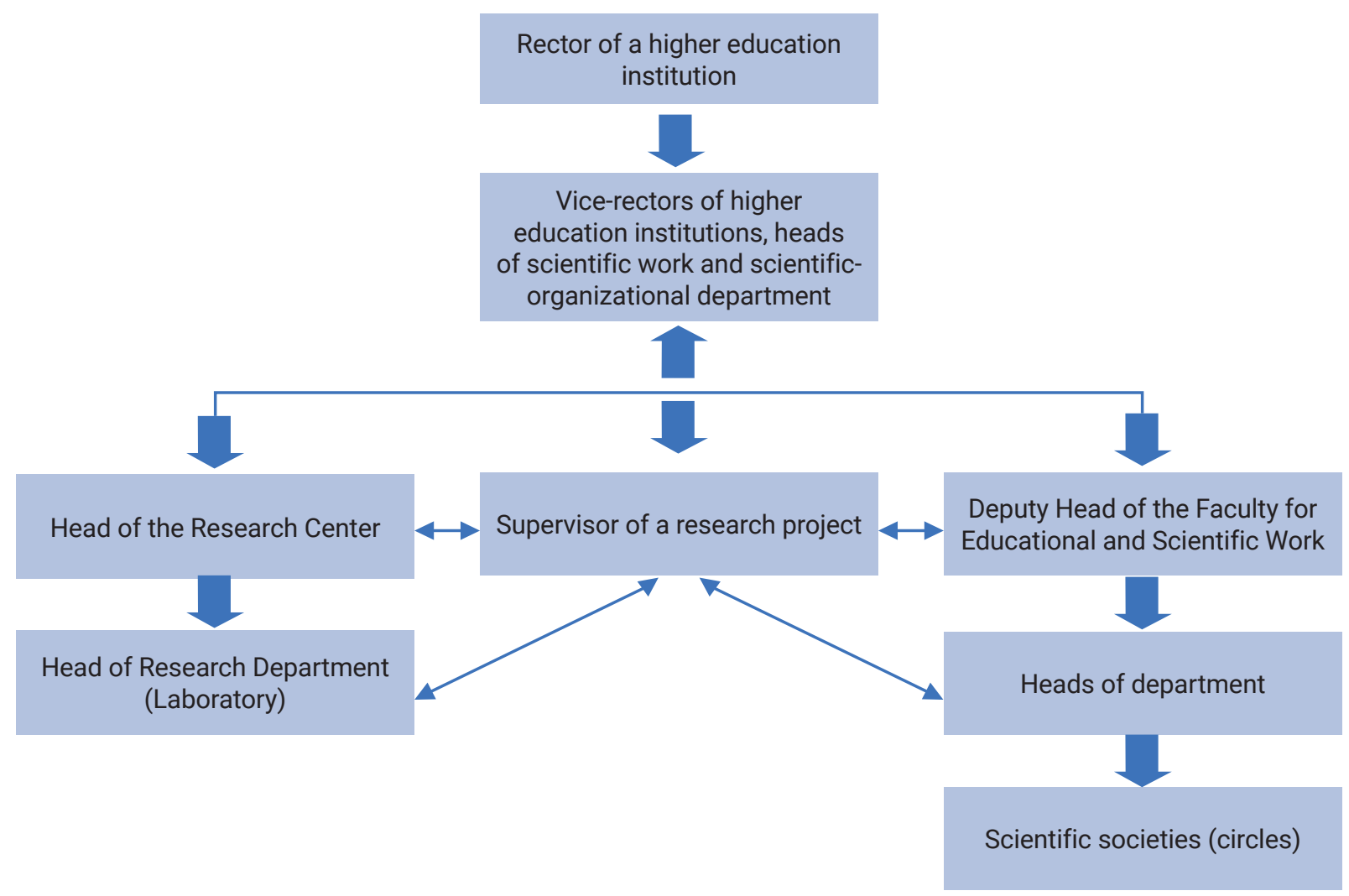

Figure 1. Vertical management in the system of higher education institutions 
An important condition for the development of scientific educational potential in the field of realization of scientific projects is the availability of sufficient financial support. According to it in the system of management of higher education institution the mechanism of commercialization of results of scientific and technical activity should be realized [5]. It will promote attraction of additional financial resources, as well as restore the effectiveness of further scientific activities. Therefore, in addition to the Ministry of Education and Science of Ukraine, law enforcement agencies of the state, departmental national universities, specialized higher educational institutions and, for the most part, enterprises whose activities are directly related to meeting the needs of higher educational institutions [10] may be interested in obtaining scientific knowledge.

In this context, the question arises of the expediency of "hiding" the full scope of scientific research results in the economic sector. According to the totality of indicators defined by regulatory legal acts of the state regarding information with restricted access, a certain number of results of scientific and technical activities does not contain signs of state secrets. It is proposed to introduce an analytical and permissive management body into the mechanism of managing scientific and technical activities, which will determine the possibility of sectoral removal of restrictions on access to documents for official use and to state secrets, that is, access to general scientific databases of certain parts, stages of scientific research, developments, methods that can be used as dual-use products in the interests of, first of all, the Ministry of Education and Science of Ukraine, through organizations that have received state funding from the defense budget, as well as for scientific institutions of other ministries (departments), institutions and business [10].

The initial stage of publication of the results of scientific projects is carried out using the accounting and reporting element of the automated scientific and technical information system in the public network. This means that open databases may publish not the result of scientific and technical activity itself, but its description, direction, certain characteristics, features, algorithms and techniques. The specified project management element should be a structural element of the scientific and technical activity management system (Fig. 2), as well as perform the function of mediation between the supplier of the results of scientific and technical activities (i.e. goods) - science units of organizations and institutions, and the consumer of this product - organizations that are interested in certain scientific developments. In such a model, the question of the cost of transferring (buying) scientific results immediately arises. Today, there are no effective mechanisms for attracting non-state funds to ensure the scientific and technical activities of the education sector, and the implementation of the proposed scheme will improve the level of financial support. This will also additionally load researchers and, accordingly, the entire scientific component, will become an additional factor in the rapid development of scientific and technical activities, will contribute to the flexibility of science and its adaptation to modern conditions of technology development and market relations.

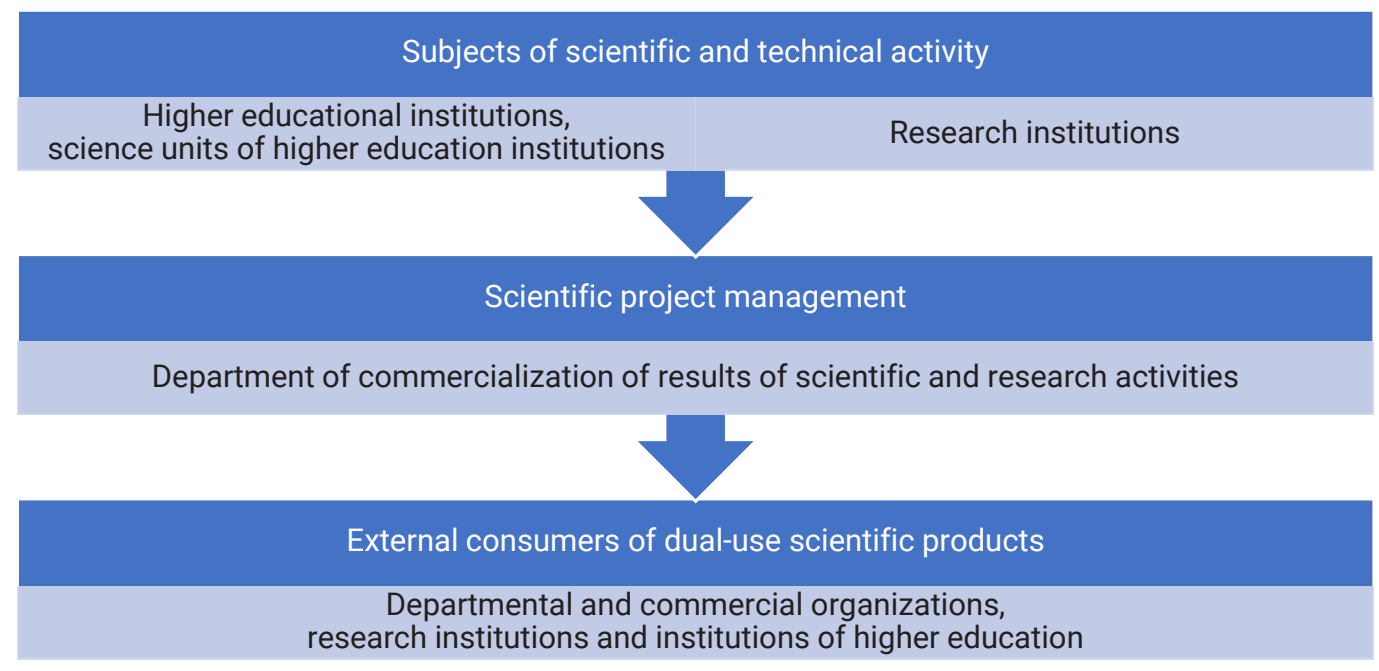

Figure 2. Block diagram of the dual-use scientific product management subsystem

Finally, it should be added that the need for commercialization of the results of scientific and technical activities is determined by the following functions of the body:

- inventory of the results of scientific and technical activities;
- formation and maintenance of a database of scientific and technical activity results;

- providing consulting services in the field of technology commercialization;

- identifying the commercial attractiveness of developments; 
- streamlining issues of intellectual property of the results of scientific and technical activities;

- attracting funding from state-owned corporations and private investors [11].

\section{Model of scientific project management in higher education institutions}

In accordance with the above, the authors propose an approach to solving the problem of optimal planning of a scientific project, which can be used as a management tool to solve the problems of the commercialization unit of the results of scientific and technical activities. Therefore, the economic and mathematical model of solving this problem is described as follows. The following designations are used:

$m$ - number of scientific projects in the planned time period;

$n$ - the number of intervals into which the planned time period is divided;

$n_{i}$ - the number of intervals during which $i$ - project can be performed, where $i=\overline{1, m}$;

$Q_{i}^{P}$ - set of sequence numbers of time intervals in which funding $i$ - project is required, provided that its implementation begins within the first time interval; $Q_{i}^{P} \subseteq\left\{1, \ldots, n_{i}\right\} ; i=\overline{1, m}$;

$Q_{i}^{D}$ - the set of serial numbers of time intervals in which it is expected to receive income from the implementation of the $i$ - project, provided that its implementation begins with the first interval; $Q_{i}^{D} \subseteq\left\{1, \ldots, n_{i}\right\} ; i=\overline{1, m}$;

$P_{i k}$ - the number of financial investments provided for $i$ - scientific project on the $k$ - time interval for its execution; $i=\overline{1, m} ; k \in Q_{i}^{P}$;

$D_{i k}$ - the amount of income from the implementation of the $i$ - research project on the $k$ - time interval of its implementation; $i=\overline{1, m} ; k \in Q_{i}^{P r}$;

Variable $x_{i k}$ is introduced. If $i$ - scientific project is accepted for execution, starting from $k$ - time interval, then $x_{i k}=1$, if not accepted, then $x_{i k}=0$.

$$
x=\left(x_{i k} \mid i=\overline{1, m} ; k \in N_{i}\right),
$$

where $N_{i}$ - set of time interval numbers during which implementation of $i$ - project can be started; $N_{i} \subseteq\left\{1, \ldots, n-n_{i}+1\right\} ; i=\overline{1, m}$.

Profit from the implementation of the $i$ research project - the difference between income and costs of implementation:

$$
b_{i}=\sum_{k \in Q_{i}^{D}} D_{i k}-\sum_{k \in Q_{i}^{P}} P_{i k} .
$$

The target function is obtained:

$$
f(x)=\sum_{i=1}^{m} b_{i} \sum_{k \in N_{i}} x_{i k} .
$$

The necessary conditions are set, such as:

1. $b_{i} \geq a_{k}$, where $a_{k}$ - the minimum allowable level of profit in $k$ - time interval, $k=\overline{1, n}$;

2. Restrictions for multiple numbers of scientific projects that may require funding in $k$ - time interval;
3. Restrictions for multiple numbers of scientific projects, which, if funded, can bring profit in $k$ - time interval, etc. [12].

This way the perspective model of management of scientific and technical activity of higher education institutions of Ukraine has been built, which contains optimized models and methods of management, takes into account the changes of organizational and structural nature in the existing system of scientific and technical activity in higher education institutions of Ukraine [6]. It should be noted that the organization of joint scientific research of higher educational institutions of Ukraine with Ukrainian scientific institutions has an extensive system of scientific departments that work on the development of science. In particular, the main role in the system is played by the National Academy of Sciences of Ukraine (NAS). A modern experimental and production base has been created in scientific institutions of the National Academy of Sciences. The Institutes of the National Academy of Sciences of Ukraine carry out fundamental research that solves the main problems of natural, technical and social sciences, as well as conduct applied research. Unlike academic research institutes, industry research institutes are mainly engaged in applied research, the purpose of which is to develop new technologies, improve and create new models of equipment for the relevant industries [13]. Therefore, the main areas of integration of scientific, scientific and technical, innovative activities of higher education institutions and research institutions of the NAS, national branch academies of sciences of Ukraine can be [8]:

- participation in the development and implementation of state targeted programs;

- conducting joint scientific research, experimental and innovative developments, etc., in particular at the expense of the state budget and own revenues;

- participation in the creation of scientific and educational, research associations, innovative structures and other organizational forms of cooperation;

- introduction of jointly created innovative products into production in the interests of the military industry etc;

- ensuring the acquisition of protection of intellectual property rights to the results of scientific and technical activities;

- implementation of joint publishing and information and resource activities;

- engagement by institutions of higher education of researchers from the NAS, national branch academies of sciences and organizations of scientific and pedagogical workers of higher educational institutions on the basis of an employment contract (agreement) for the implementation of educational and scientific activities, in particular for the training of postgraduates and doctoral students, preparation and examination of textbooks, manuals, educational programs and standards of higher education to support the educational process in higher education;

- organization of scientific research of young scientists, 
doctoral students and postgraduates on the basis of the NAS, national branch academies of sciences and institutions of higher education of Ukraine, systematic industrial practice of students of higher education institutions with their direct participation in conducting scientific research [14].

Organization planning and implementation of joint scientific research in higher educational institutions with NAS institutions is carried out on the basis of an agreement in the following areas:

- organization of implementation of the achieved results of NAS institutions based on the results of the implementation of the target scientific and technical program of the academy "Research and Development on Problems of Increasing the Defense Capability of the State";

- preparation of proposals on the implementation by institutions of the NAS in the calendar year of applied research needs of education in Ukraine and their inclusion in the state defense order.

\section{International cooperation in the management of educational projects of higher educational institutions}

It is worth noting that there are many ways of international scientific and scientific-technical cooperation [15]. In the context of optimizing the management of educational projects, it is necessary to pay attention to the following:

- conducting joint scientific research, technical and technological developments on the basis of cooperation, joint scientific and technical programs, coordination agreements;

- carrying out the work stipulated in the agreement, one party to which is an organization of a foreign state or an international organization;

- conducting joint research and development with international teams of specialists, international institutes and joint ventures, using ownership rights to scientific and technical (applied) results on the basis of agreements between subjects of scientific and technical activities;

- mutual exchange of scientific and technical information, use of joint international information funds, data banks;

- conducting international conferences, congresses, and symposia;

- mutual exchange of scientific, scientific-technical and scientific-pedagogical personnel, students and postgraduates, as well as joint training of specialists;

- participation in international research programs, in particular, the EU Framework Programmes for Research and Innovation

Economic entities of scientific and technical activities may participate in the implementation of international scientific and technical programs and projects, also enter into agreements with foreign organizations and legal entities, participate in foreign and international scientific societies, associations and unions as their members, enter into contracts with foreign organizations and legal entities, participate in international symposia and other events in accordance with the laws of Ukraine [8]. The state ensures the integration of the national research space into the European research space by implementing its priorities, in particular improving the effectiveness of the national research system; optimizing international cooperation in order to solve global problems facing humanity; ensuring participation in the EU framework and joint international programs; coordinating the strategy for creating state research infrastructures with the roadmap of European research infrastructures; creating favorable conditions for the mobility of scientists; full exchange, transfer and access to scientific knowledge [16].

At the same time, it should be noted that the system of scientific and technical activities of the world's leading countries is based on the principles of dynamism and proactivity in order to avoid obsolescence and compliance with scientific and technological progress. For example, to facilitate close ties with academia, industry, and the innovative private sector, the Army Futures Command (AFC) headquarters (a component responsible for advanced military research for the US Army) was located on the campus of the University of Texas [17]. There are 8 multi-functional teams working within the AFC (Cross-Functional Teams, CFT), which develop requirements obtained through experiments and technical demonstrations for a number of priority areas of ability development, such as: synthetic learning environment.

As a result of the conducted analytical research, the outline of a promising model of scientific and technical activities of higher educational institutions of Ukraine is created, as well as the main directions of applying efforts to improve the efficiency of the system of scientific and technical activities are formulated, namely:

- in the general structure of the system of scientific and technical activities of higher educational institutions of Ukraine, it is proposed to introduce state bodies of control and coordination of science, as well as mandatory integration with the Ukrainian and world scientific and technical environment, enterprises. In particular, in this context, it was a question of granting real powers and registration as a full-fledged element of the system of providing scientific and technical activities to ensure the already existing system of these activities;

- proposals are made to include in the structure of the scientific and technical activity management system the commercialization body of the results of scientific and technical activities, which will improve the level of financial support, additionally load the scientific component, and also contribute to the flexibility of military science and its integration into the scientific, technical and industrial environment. An approach to solving the problem of optimal planning of scientific projects is proposed.

- recommendations on the shift from the rigid hierarchical structure and granting additional authority to heads of scientific projects in higher educational institutions in terms of managing scientific projects are substantiated.

- recommendations have been developed to involve the personnel of science units in international cooperation, participate in events for the exchange of experience, and 
create mixed working groups in events of scientific and technical cooperation and interaction.

\section{Conclusions}

In the course of research, based on the analysis of the existing management system of scientific and technical activities, world and national experience in this field, the main directions of effective improvement of scientific project management is determined. It is established that the state provides subjects of scientific and technical activity with the necessary legal and economic conditions for carrying out further activities and establishing relations based on cooperation with scientific and scientific-technical organizations, as well as enterprises of national and international level. In the context of improving the efficiency of scientific project management, the author provides advice on organizing joint international scientific research. It is revealed that the existing methodological apparatus does not provide comprehensive tools for fully supporting the tasks of managing scientific projects in higher education institutions. Taking into account the studied features and specifics of scientific projects in the education sector, resources, activities and processes are identified, the impact on which optimizes the management of scientific projects in higher educational institutions, a list of management models and methods is formulated that reveal in more detail the content of scientific projects and management processes in them, give managers of scientific and technical activities in higher educational institutions additional opportunities and levers of influence on the project. Prospects for further research are seen in the practical implementation of the developed model of managing scientific projects within the activities of higher educational institutions for experimental confirmation of its effectiveness.

\section{References}

[1] Oliveira, D., Neves, J., Raposo, D., \& Silva, J. (2020). Research project management in communication design: Methodology proposal. Advances in Intelligent Systems and Computing, 1203, 96-102.

[2] Chin, C.M.M., Spowage, A.C., Yap, E.H., \& Lee, C.W. (2011). Developing a project management methodology for use in doctoral research projects. Journal of Institutional Research South East Asia, 9(1), 5-26.

[3] Sankaran, S., Müller, R., \& Drouin, N. (2021). Investigating collaboration in project management research: Using action research as a meta-methodology. International Journal of Managing Projects in Business, 14(1), 205-230.

[4] Piwowar-Sulej, K. (2021). Organizational culture and project management methodology: Research in the financial industry. International Journal of Managing Projects in Business, 14(6), 1270-1289.

[5] Domnin, L.N. (2007). Elements of graph theory. Penza: Penza State University.

[6] Bulhakov, R., \& Holovan, V. (2020). Directions for improving the effectiveness of managing scientific projects in higher military institutions. Systems of Arms and Military Equipment, 2(62), 109-118. doi: 10.30748/soivt.2020.62.14.

[7] Novikov, D.A., \& Sukhanov, A.L. (2005). Models and mechanisms for managing research projects in universities. Moscow: Institute of Education Management of the RAE.

[8] Pedan, F., Rudenska, G., Tkachenko, M., \& Fedorenko, R. (2016). Comparative analysis of information systems of automation of processes of management of financial-economic activity. Collection of the Scientific Papers of the Centre for Military and Strategic Studies of the National Defence University of Ukraine named after Ivan Chermiakhovskyi, 2, 95-100.

[9] Law of Ukraine No. 848-VIII “About Scientific and Scientific-Technical Activity”. (2015, November). Retrieved from https://zakon.rada.gov.ua/laws/show/848-19/ed20151126\#Text.

[10] Bulhakov, R., \& Holovan, V. (2019). Perspective model of information supply of scientific projects management system in higher military educational institutions. Collection of Scientific Works of Odesa Military Academy, 1(11), $130-136$.

[11] Kramskyi, S., Danchuk, V., Alkema, V., Sevostianova, A., \& Bakulich, O. (2020). Wheel working system in a team: Relationship between different personnel in a marine project. Financial and Credit Activity: Problems of Theory and Practice, 4(35), 277-286.

[12] Kramskyi, S. (2021). Methods of optimization of scientific and technical activity for scientific projects of a private institution of higher education. Management of Development of Complex Systems, 45, 35-42.

[13] Sirazitdinova, Y., Dulzon, A., \& Mueller, B. (2015). Project management practices in engineering university. IOP Conference Series: Materials Science and Engineering, 93(1), article number 012080.

[14] Fowler, N., Lindahl, M., \& Sköld, D. (2015). The projectification of university research: A study of resistance and accommodation of project management tools \& techniques. International Journal of Managing Projects in Business, 8(1), 9-32.

[15] Mitrofanova, Y.S., Chehri, A., Tukshumskaya, A.V., Vereshchak, S.B., \& Popova, T.N. (2021). Project management of smart university development: Models and tools. Smart Innovation, Systems and Technologies, 240, 339-350.

[16] Fernandes, G., O’ Sullivan, D., Pinto, E.B., Araújo, M., \& Machado, R.J. (2020). Value of project management in university-industry R\&D collaborations. International Journal of Managing Projects in Business, 13(4), 819-843.

[17] Project Management Institute. (2017). A guide to the project management body of knowledge. Retrieved from http://faspa.ir/wp-content/uploads/2017/09/PMBOK6-2017.pdf. 


\title{
Модель обґрунтування організаційної структури системи управління закладів вищої освіти \\ Сергій Олександрович Крамський', Анна Юріївна Стренковська², Олег Володимирович Захарченко²
}

\author{
${ }^{1}$ Одеський інститут Міжрегіональної академії управління персоналом \\ 65003, вул. Чорноморського козацтва, 19, м. Одеса, Україна \\ ${ }^{2} 0$ деська державна академія будівництва та архітектури \\ 65029, вул. Дідріхсона, 4, м. Одеса, Україна
}

\begin{abstract}
Анотація. Актуальність дослідження визначається потребою в оновленні структури управління науковими проєктами в межах закладів вищої освіти відповідно до сучасних економічних реалій і міжнародно визнаних стандартів, суть якого полягає у відході від жорсткої ієрархічної системи управління та орієнтації на комерціалізації результатів науково-технічної діяльності. Відтак, метою наукової статті є розроблення функціональної моделі управління науковими проєктами в межах вищої освіти, складові якої, на відміну від наявних моделей, будуть характеризуватися проєктно-орієнтованим спрямуванням. Для досягнення визначеної мети дослідження використовувались загальнонаукові методи дослідження, серед яких аналіз, синтез, узагальнення, порівняння, систематизація, моделювання, а також структурний і математичний методи, з урахуванням ключових принципів структурно-функціонального та системного підходів. У статті проаналізовано низку наукових праць українських і зарубіжних вчених із теми методологічного обгрунтування специфіки управління науковими проєктами у вищих навчальних закладах. Визначено ключові проблеми сучасного стану управління науковими проєктами в межах українського наукового простору, зокрема жорстку організаційно-штатну структуру управління 3 переважною роллю вищого керівника, недостатнє фінансове забезпечення науково-технічної діяльності, а також обмежений доступ до результатів науково-технічної діяльності. Розроблено авторську економіко-математичну модель управління науковими проєктами в закладах вищої освіти з урахуванням функціональних показників. Запропоновано впровадження органу комерціалізації результатів науково-технічної діяльності, який сприятиме оптимізації фінансового забезпечення науково-технічної діяльності. Обгрунтовано необхідність у розвитку міжнародного співробітництва в межах науково-технічної діяльності та організації наукових проєктів зокрема. Практична цінність наукової роботи полягає в розробленні власного методичного забезпечення належного функціонування управління науковими проєктами з перспективою його подальшого застосування на практиці
\end{abstract}

Ключові слова: економічна модель, науковий проєкт, вищі навчальні заклади, науково-технічна діяльність 